\title{
In vitro antifungal susceptibility of Candida spp. oral isolates from HIV- positive patients and control individuals
}

\begin{abstract}
Graziella Nuernberg Back Brito(a) Aline Cássia Inocêncio(a)

Sílvia Maria Rodrigues Querido(a) Antonio Olavo Cardoso Jorge ${ }^{(a)}$ Cristiane Yumi Koga-Ito(a)
\end{abstract}

(a) Department of Biosciences and Oral Diagnosis, São José dos Campos Dental School, UNESP, Univ Estadual Paulista, SP, Brazil.

\section{Corresponding author:}

Cristiane Yumi Koga-lto

Av. Engenheiro Francisco José Longo, 777 -

Jd. São Dimas

São José dos Campos - SP - Brazil

CEP: 12245-000

E-mail:cristiane@fosjc.unesp.br

Received for publication on Jul 15, 2010 Accepted for publication on Sep 27, 2010

\begin{abstract}
Oropharyngeal candidiasis is the most common fungal infection among HIV-positive patients. This condition can be treated with either systemic or topical antifungal agents; treatments are usually indicated empirically on the basis of clinical data. The knowledge of in vitro antifungal susceptibility is important to determine correct therapeutic guides for the treatment of fungal infections. Therefore, the objective of this study was to determine the antifungal susceptibility profile of oral Candida isolates from HIV-positive patients and control individuals. Amphotericin B, fluconazole, flucytosine, nystatin and ketoconazole were tested according to the methodology of microdilution proposed by the Clinical and Laboratory Standards Institute (CLSI); results were recorded in values of minimal inhibitory concentration (MIC). A total of 71 Candida isolates from HIV-positive patients were examined with the following species represented: C. albicans (59), C. tropicalis (9), C. glabrata (1), C. guilliermondii (1) and C. krusei (1). A total of 15 Candida isolates were evaluated from control individuals comprised of 11 C. albicans and 4 C. tropicalis samples. Our results demonstrated that the tested antifungal agents showed good activity for most isolates from both groups; however, variability in MIC values among isolates was observed.
\end{abstract}

Descriptors: HIV; Antifungal Agents; Candida.

\section{Introduction}

The oral cavity is inhabited by more than seven hundred microbial species; many intrinsic and extrinsic factors impact the composition, metabolic activity, and pathogenicity of these highly diversified oral microflora. ${ }^{1,2}$ Yeasts from the Candida genus are commonly found in oral human microflora and are considered to comprise the majority of fungal species present in the oral cavity. Although the growth of Candida in the oral cavity is usually controlled, under certain conditions Candida species can rapidly multiply resulting in disease and possible tissue invasion. The incidence of oropharyngeal candidosis has increased over the last several decades due to the widespread use of antibiotics, antifungal drugs and immunosuppressive drugs and some conditions, such as HIV-infection. ${ }^{2,3,4}$ Oropharyngeal candidosis is the most common fungal infection among patients infected with HIV. Oral candidosis occurs in more than 95\% of AIDS patients, and it is considered an important marker of the AIDS disease and its progression. The prevalence of oral candidosis in 
HIV-positive patients appears to be correlated to the severity of immunological disfunction. ${ }^{5,6}$ The occurrence of oral candidosis at initial stages of AIDS is common, particularly when the CD4 T cell count is low $\left(400-700\right.$ cells $\left./ \mathrm{mm}^{3}\right) .^{5}$

The widespread use of antifungal agents to prevent the occurrence of oral candidosis in HIV-infected patients has been cited as an important factor for the positive selection of non-albicans species as opportunistic pathogens; these species have different susceptibilities to the antifungal agents utilized to treat C. albicans. ${ }^{7}$ Certain non-albicans species, such as C. glabrata and C. krusei, are inherently less susceptible to fluconazole than C. albicans and have been isolated with increasing frequency in HIV-infected patients. ${ }^{7,8,9,10,11}$

The increasing resistance to antifungal treatments and expanding drug therapy options has prompted the need for clinically relevant antifungal susceptibility testing; these results could act as a guide in the selection and control of antifungal therapy. For this purpose, the Clinical and Laboratory Standards Institute (CLSI) proposed a reference method for yeast antifungal susceptibility testing using serial dilutions and obtained values of minimal inhibitory concentration. ${ }^{12,13,14}$

Fluconazole is considered to be the drug of choice for the treatment of most common HIVassociated opportunistic yeast infections. ${ }^{14,15}$ It has been the most widely used drug because of its good absorption, low toxicity and ability to be administered through both oral and intravenous routes. ${ }^{16}$ Fluconazole resistance is associated with prolonged exposure to azoles. ${ }^{14,17}$ Further, in 2002 Espinel-Ingroff ${ }^{18}$ reported an association between the in vitro resistance of Candida to fluconazole and clinical failure in the treatment of candidosis. Ketoconazole is the first drug of the azole class of agents capable of achieving therapeutic blood levels when administered orally. While ketoconazole is used to treat immunocompromised patients, its adverse side effects, including nausea and hepatotoxicity, has restricted its use. ${ }^{19}$ However, despite the toxicity, it shows several adverse drug interactions, disabling its use in association with some drugs, including antiretrovirals. ${ }^{16}$ The antifungal drug amphotericin B decreases the adherence of Candida to buccal epithelial cells and can interfere in the pathogenesis of candidosis. The use of amphotericin B in dentistry is common; it is indicated for the treatment of superficial candidosis cases and is used locally. The systemic use is generally indicated for the treatment of disseminated cases and is highly toxic to the patient, causing kidney disorders. ${ }^{16}$ The antifungal drug flucytosine has better gastrointestinal absorption compared to amphotericin B. However, flucytosine also has toxicity, negatively impacting metabolic and liver function. ${ }^{19}$

Based on this information, it can be observed that all antifungals have "pros and cons" when used in the treatment of candidosis. Thus, the evaluation of the susceptibility profile of oral Candida isolates is important in determining the proper method of treatment in candidosis. The objective of this study was to determine the antifungal susceptibility profile of oral Candida isolates from HIV-positive patients and control individuals.

\section{Materials and Methods}

Oral rinses and dental biofilm samples were collected from HIV-positive patients and control individuals. The isolates were identified by germ tube test, hyphae/pseudohyphae, chlamydospore formation, assimilation and fermentation of carbohydrates as previously described ${ }^{20}$ (Local Ethics Committee 012-PH/CEP).

In total, 59 C. albicans, 9 C. tropicalis, 1 C. glabrata, 1 C. guilliermondii and 1 C. krusei isolates from HIV-positive patients and 11 C. albicans and 4 C. tropicalis isolates from control individuals were evaluated.

The isolates were inoculated onto Sabouraud dextrose agar and were incubated for $48 \mathrm{~h}$ at $37^{\circ} \mathrm{C}$. After this period, the colonies were suspended in sterile saline solution $(0.85 \% \mathrm{NaCl})$ resulting in an initial concentration of $1.5 \times 10^{6}$ cells $/ \mathrm{ml}$. Subsequently, the suspension was diluted in 1:2000 in RPMI 1640 medium (Sigma, St. Louis, USA) and buffered to $\mathrm{pH} 7.0$ with $0.165 \mathrm{M}$ morpholinepropanesulfonic acid (Sigma, St. Louis, USA) to obtain a final concentration of $0.5 \times 10^{3}-2.5 \times 10^{3}$ cells/ $\mathrm{ml}$. 
The antifungal agents tested were: amphotericin B (Sigma Chemical Company, St. Louis, USA), fluconazole (Galena Chemical and Farmacêutica, São Paulo, Brazil), ketoconazole (Galena Chemical and Farmacêutica, São Paulo, Brazil), nystatin (Galena Chemical and Farmacêutica, São Paulo, Brazil) and flucytosine (Sigma Chemical Company, St. Louis, USA). Amphotericin B and ketoconazole were dissolved in dimethylsulfoxide (Sigma, Irvine, United Kingdom). The other antifungal agents were dissolved in sterile distilled water. The drugs were prepared at the following concentrations: $320 \mu \mathrm{g} /$ $\mathrm{ml}$ for amphotericin $\mathrm{B}, 1000 \mu \mathrm{g} / \mathrm{ml}$ for flucytosine, $1250 \mu \mathrm{g} / \mathrm{ml}$ for fluconazole, and $640 \mu \mathrm{g} / \mathrm{ml}$ for ketoconazole. The solutions were diluted in RPMI medium and final drug concentrations ranged from 64 to $0.03 \mu \mathrm{g} / \mathrm{ml}$. Antifungal susceptibility was determined by the microdilution method in 96-well microplates as described by the CLSI. ${ }^{21}$ An aliquot of $100 \mu \mathrm{L}$ of the final concentration of antifungal drug and $100 \mu \mathrm{L}$ of the inoculum test sample were added to each well. The plates were incubated at $37^{\circ} \mathrm{C}$ and readings were performed after $48 \mathrm{~h}$. The plates with amphotericin B were covered with aluminum foil to protect against light. Result readings were based on the visual scale of turbidity of control tubes represented by: 0 (completely clear), 1 (slightly cloudy), 2 (intermediate turbidity), 3 (prominent turbidity) and 4 (completely cloudy).

For the members of the azole drug class and flucytosine, the MIC were defined as the lowest drug concentration that resulted in $80 \%$ growth inhibition. For amphotericin B, this value was defined as the value in which $100 \%$ growth inhibition was observed.

The results are expressed as ranges of minimum and maximum MIC values and the values of $\mathrm{MIC}_{50}$ and $\mathrm{MIC}_{90}$. These values represent the drug concentration that inhibits the growth of $50 \%$ and $90 \%$ of the isolates, respectively. C. parapsilosis ATCC 22019 was used as a reference for quality control in all the experiments.

The endpoints for fluconazole, flucytosine and ketoconazole considered for the classification of the isolates followed the values of the CLSI ${ }^{21}$ represented in Table 1. There were no CLSI endpoints defined for amphotericin B and nystatin.

\section{Results}

The number of isolates from both studied groups according to the MIC value for each tested drug is displayed in Table 2.

The results obtained for Candida isolates to the drugs tested are presented in Table 3. The values are

\begin{tabular}{|c|c|c|c|c|c|}
\hline \multirow{3}{*}{$\begin{array}{r}\text { Table } 1 \text { - Endpoints for } \\
\text { fluconazole, flucytosine } \\
\text { and ketoconazole } \\
(\mu \mathrm{g} / \mathrm{m}) .\end{array}$} & Antifungal agents & Susceptible & S-DD & Intermediate & Resistant \\
\hline & Fluconazole & $\geq 8$ & $16-32$ & - & $\geq 64$ \\
\hline & Flucytosine & $\leq 4$ & - & $8-16$ & $\geq 32$ \\
\hline & Ketoconazole & $\leq 8$ & - & - & $>16$ \\
\hline
\end{tabular}

S-DD: susceptible dose-dependent.

Table 2 - Distribution of Candida spp. according to the MIC of each antifungal agent tested.

\begin{tabular}{|c|c|c|c|c|c|c|c|c|c|c|c|c|}
\hline \multicolumn{13}{|c|}{ Number of isolates inhibited at concentrations $(\mu \mathrm{g} / \mathrm{ml})$ of: } \\
\hline & 0.03 & 0.06 & 0.125 & 0.25 & 0.5 & 1 & 2 & 4 & 8 & 16 & 32 & 64 \\
\hline Ampho & 1 & 6 & 4 & 12 & 43 & 15 & 3 & 2 & 0 & 0 & 0 & 0 \\
\hline Fluco & 0 & 0 & 7 & 36 & 42 & 1 & 0 & 0 & 0 & 0 & 0 & 0 \\
\hline Flucy & 0 & 9 & 20 & 27 & 10 & 17 & 1 & 2 & 0 & 0 & 0 & 0 \\
\hline Keto & 5 & 41 & 15 & 17 & 0 & 6 & 0 & 2 & 0 & 0 & 0 & 0 \\
\hline Nyst & 0 & 0 & 0 & 0 & 0 & 1 & 66 & 18 & 1 & 0 & 0 & 0 \\
\hline
\end{tabular}

Ampho, amphotericin B; Fluco, fluconazole; Flucy, flucytosine; Keto, ketoconazole; Nyst, nystatin. 


\begin{tabular}{|c|c|c|c|c|c|}
\hline \multirow{6}{*}{$\begin{array}{r}\text { Table } 3-\mathrm{MIC}_{50} \\
\mathrm{MIC}_{90^{\prime}} \text { range } \\
\text { values }(\mu \mathrm{g} / \mathrm{ml}) \\
\text { and percentage of } \\
\text { resistant isolates } \\
\text { obtained. }\end{array}$} & Antifungal drug & $\mathrm{MIC}_{90}$ & $\mathrm{MIC}_{50}$ & Minimum-maximum & $\begin{array}{c}\% \text { resistant } \\
\text { isolates }\end{array}$ \\
\hline & Amph & 1 & 0.5 & $0.03-4$ & $-{ }^{*}$ \\
\hline & Fluco & 0.5 & 0.25 & $0.125-1$ & 0 \\
\hline & Fluky & 1 & 0.25 & $0.06-4$ & 0 \\
\hline & Keto & 0.25 & 0.06 & $0.03-4$ & 0 \\
\hline & Nyst & 4 & 2 & $1-8$ & $-{ }^{*}$ \\
\hline
\end{tabular}

Amph B, amphotericin B; Fluco, fluconazole; Flucy, flucytosine; Keto, ketoconazole; Nyst, nystatin; MIC $_{50}$ minimal inhibitory concentration values for $50 \%$ of the isolates; $\mathrm{MIC}_{90}$, minimal inhibitory concentration values for $90 \%$ of the isolates; * no endpoints defined by the CLSI. ${ }^{21}$

Table 4 - Values of MIC range $(\mu \mathrm{g} / \mathrm{ml})$ for Candida spp. according to antifungal drug.

\begin{tabular}{|c|c|c|c|c|c|c|c|}
\hline & \multirow{2}{*}{ Species } & \multirow{2}{*}{$\mathrm{N}$} & \multicolumn{5}{|c|}{ MIC range } \\
\hline & & & amph & fluco & flucy & keto & nyst \\
\hline \multirow{5}{*}{$\begin{array}{l}\text { HIV- } \\
\text { infected } \\
\text { group }\end{array}$} & C. albicans & 59 & $0.06-4$ & $0.125-1$ & $0.06-4$ & $0.03-4$ & $1-8$ \\
\hline & C. glabrata & 1 & 0.5 & 0.5 & 2 & 0.25 & 2 \\
\hline & C. guilliermondii & 1 & 0.125 & 0.25 & 0.125 & 0.03 & 4 \\
\hline & C. krusei & 1 & 0.5 & 0.25 & 0.125 & 0.03 & 4 \\
\hline & C. tropicalis & 9 & $0.03-0.5$ & $0.25-0.5$ & $0.125-0.5$ & $0.06-4$ & $2-4$ \\
\hline \multirow{2}{*}{$\begin{array}{l}\text { Control } \\
\text { group }\end{array}$} & C. albicans & 11 & $0.125-2$ - & $0.125-0.5$ & $0.06-4$ & $0.06-0.25$ & 2 \\
\hline & C. tropicalis & 4 & $0.125-0.5-$ & $0.25-0.5$ & $0.06-1$ & $0.03-0.25$ & $2-4$ \\
\hline
\end{tabular}

$\mathrm{N}$, number of isolates; Amph, amphotericin B; Fluco, fluconazole; Flucy, flucytosine; Keto, ketoconazole; Nyst, nystatin; MIC, minimal inhibitory concentration.

expressed as ranges of MICs, as well as $\mathrm{MIC}_{50}$ and $\mathrm{MIC}_{90}$ values. The MIC ranges for all the isolates from the control and HIV-infected groups indicate susceptibility to fluconazole, flucytosine and ketoconazole.

The distribution of the species isolates of each group according to the range concentration of the drugs studies is shown in Table 4.

\section{Discussion}

Despite the increasing number of commercially available antifungal drugs in recent years, antifungals are still at a disadvantage when compared to antibacterial drugs. Resistance to antifungal drugs also represents a great clinical challenge. Given the difficulties observed in the treatment of fungal infections in some groups of patients, isolation of the causative infectious agent and identification of the susceptibility profile of the yeast isolate are recommended. In this context, screening studies for antifungal resistance are of the utmost importance.

The incidence of clinical fluconazole resistance varies in the literature from $5-15 \% .{ }^{14}$ Lyon et al. ${ }^{22}$ observed that $90 \%$ of C. albicans, C. parapsilosis and C. tropicalis isolates were inhibited by fluconazole at a concentration of $2.0 \mu \mathrm{g} / \mathrm{ml}$; further, there was no difference between the samples obtained from denture wearers and from patients with natural teeth. However, in C. glabrata isolates, the $\mathrm{MIC}_{90}$ value reached $8 \mu \mathrm{g} / \mathrm{ml}$ for samples obtained from denture wearers. Interestingly, this study found that all C. krusei isolates were resistant. These results contrast with our findings; we found all isolates to be susceptible to fluconazole.

For ketoconazole, all isolates were susceptible in both groups; isolates from HIV-infected patients showed MIC values between $0.03-4.0 \mu \mathrm{g} / \mathrm{ml}$ while the MIC values ranged from $0.03-0.25 \mu \mathrm{g} / \mathrm{ml}$ for the isolates from control patients. Ketoconazole has been used in the treatment of superficial infections in dentistry patients. However, its use in dentistry is predominately restricted to local administration, as systemic treatment can be highly toxic to the patient. ${ }^{23}$ Similar values for azoles have been reported, 
as in the study of Wingeter et al. ${ }^{13}$ They reported that from oral isolates, $72 \%$ were sensitive to ketoconazole $(\mathrm{MIC}<1 \mu \mathrm{g} / \mathrm{ml})$, and $86 \%$ of the isolates were susceptible to fluconazole (MIC $<8 \mu \mathrm{g} / \mathrm{ml}$ ).

There are no endpoints for amphotericin B defined by the CLSI; ${ }^{21}$ therefore, we could not classify our results for this drug as susceptible or resistant. However, Sutton et al. ${ }^{24}$ suggested the values of $<1 \mu \mathrm{g} / \mathrm{ml}$ for an isolate to be considered susceptible and $>2 \mu \mathrm{g} / \mathrm{ml}$ for resistance to amphotericin $\mathrm{B}$ as endpoints. If we consider these values for classification, $94.4 \%$ of isolates from the HIV-infected group and $93.3 \%$ of isolates from the control group were susceptible. Further, this parameter showed that $C$. albicans was the species with the highest level of resistance. This result is in accordance with results published by Rautemaa et al. ${ }^{25}$ who reported that most isolates of C. albicans were sensitive to amphotericin B. Further, Wingeter et al. ${ }^{13}$ reported that despite over 50 years of use of polyene antifungal drugs, resistance to amphotericin $B$ is rare. However, in their study 2 of 57 isolates showed MIC $>2 \mu \mathrm{g} / \mathrm{ml}$ for amphotericin $\mathrm{B}$, indicating resistance. Batista et al. ${ }^{26}$ studied isolates from patients with total dentures and observed good fungistatic activity of amphotericin B with MIC values ranging from $0.03-0.15 \mu \mathrm{g} / \mathrm{ml}$. Lyon et al. ${ }^{22}$ reported a $\mathrm{MIC}_{90}$ value of $1.0 \mu \mathrm{g} / \mathrm{ml}$ for all isolates, regardless of whether they were taken from denture wearers or individuals with natural teeth.

Alves et al. ${ }^{27}$ found that among isolates susceptible to fluconazole, the activity of flucytosine was highest against C. albicans (84.6\%) and C. glabrata (94.1\%). Additionally, they reported that $40 \%$ of $C$. $\mathrm{krusei}$ isolates were susceptible to flucytosine. Alves et al. ${ }^{27}$ have argued that the great potential of flucytosine against C. glabrata has not been sufficiently explored and that this antifungal may be used as a treatment option when resistance to azoles is ob-

\section{References}

1. Samaranayake LP, Fidel PL, Naglik JR, Sweet SP, Teanpaisan $\mathrm{R}$, Coogan MM, et al. Fungal infections associated with HIV infection. Oral Dis. 2002;8 Suppl 2:151-60. served. In our study, the C. glabrata isolate was susceptible to fluconazole and flucytosine.

In a study evaluating oral isolates from patients with periodontal disease, ${ }^{12}$ it was observed that all isolates were susceptible to amphotericin B and fluconazole. However, the same was not observed for ketoconazole; one isolate of C. albicans and C. glabrata from the periodontitis group and one isolate of Candida spp. from the control group were resistant. In the same study, only one isolate of $C$. albicans from the periodontitis group was resistant to flucytosine. In our study, while all isolates were susceptible to the azole drugs, strains of C. albicans showed a wide variation in MIC values. This finding was especially prominent in isolates from the HIVinfected group.

The antifungal drug nystatin has been reported in the literature to be widely used in fungal infections in the oral cavity. ${ }^{28}$ In this study, the range of MICs for nystatin was similar to those reported by Hamza et al. $;^{29}$ they reported intervals between 2 16 for C. albicans and 2 - 4 for C. glabrata and C. tropicalis. Wingeter et al. ${ }^{13}$ adopted the following end points: $\leq 4$, susceptible; 8 - 32 , susceptible dosedependent; and $\geq 64$, resistant. In our study, only one isolate from the HIV-infected group had a MIC value of $8 \mu \mathrm{g} / \mathrm{ml}$; all other isolates were susceptible to nystatin. This result is in accordance with a previous study that reported that $95 \%$ of isolates were susceptible. $^{13}$

\section{Conclusion}

Our results demonstrate that the tested antifungal agents showed good activity for most isolates of both groups; however, variability found among isolates and resistance to antifungal agents confirmed the importance of susceptibility tests as a guide to the therapeutic prescription of antimycotics.

2. Aas JA, Paster BJ, Stokes LN, Olsen I, Dewhirst FE. Defining the normal bacterial flora of the oral cavity. J Clin Microbiol. 2005 Nov;43(11):5721-32. 
3. Jabra-Rizk MA, Falkler WA Jr, Enwonwu CO, Onwujekwe DI Jr, Merz WG, Meiller TF. Prevalence of yeast among children in Nigeria and the United States. Oral Microbiol Immunol. 2001 Dec;16(6):383-5.

4. Laupland KB, Gregson DB, Church DL, Ross T, Elsayed S. Invasive Candida species infections: a 5 year population-based assessment. J Antimicrob Chemother. 2005 Sep;56(3):532-7.

5. Lin AL, Johnson DA, Patterson TF, Wu Y, Lu DL, Shi Q, et al. Salivary anticandidal activity and saliva composition in a HIV-infected cohort. Oral Microbiol Immunol. 2001 Oct;16(5):270-8.

6. Al-Abeid HM, Khaled HA, Elkarmi AZ, Hamad MA. Isolation and characterization of Candida spp. in Jordanian cancer patients: prevalence, pathogenic determinants, and antifungal sensitivity. Jpn J Infect Dis. 2004 Dec;57(6):279-84.

7. Schorling SR, Kortinga HC, Froschb M, Mühlschlegel FA. The role of Candida dubliniensis in oral candidiasis in human immunodeficiency virus-infected individuals. Crit Rev Microbiol. 2000;26(1):59-68.

8. Alves SH, Silva GM, Scopel PA, Oliveira LTO, Costa JM, Milan $\mathrm{EP}$, et al. Isolamento de Candida dubliniensis da mucosa oral de um paciente com SIDA no Rio Grande do Sul. Rev AMRIGS. 2000 Jul-Dez;44(3,4):185-7.

9. Redding SW, Kirpatrick WR, Dib O, Fothergill AW, Rinaldi MG, Patterson TF. The epidemiology of non-albicans Candida in oropharyngeal candidiasis in HIV patients. Spec Care Dentist. 2000 Sep-Oct;20(5): 178-81.

10. Crocco EI, Mimica LMJ, Muramatu LH, Garcia C, Suza VM, Ruiz LRB, et al. Identificação de espécies de Candida e susceptibilidade antifúngica in vitro: estudo de 100 pacientes com candidíases superficiais. An Bras Dermatol. 2004 NovDez;79(6):689-97.

11. Ship JA, Vissink A, Chalacombe ST. Use of prophylactic antifungals in the immunocompromised host. Oral Surg Oral Med Oral Pathol Oral Radiol Endod. 2007 Mar;103 Suppl:S6. e1-14.

12. Koga-Ito CY, Martins CAP, Loberto JCS, Santos SSF, Jorge AOC. In vitro antifungal susceptibility of Candida spp. Isolates from patients with chonic periodontitis and from control patients. Braz Oral Res. 2004 Jan-Mar;18(1):80-4.

13. Wingeter MA, Guilhermetti E, Shinobu CS, Takaki I, Svidzinski TIE. Identificação microbiológica e sensibilidade in vitro de Candida isoladas da cavidade oral de indivíduos HIV positivos. Rev Soc Bras Med Trop. 2007 May-Jun;40(3):272-6.

14. Enwuru CA, Ogunledun A, Idika N, Enwuru NV, Ogbonna $\mathrm{F}$, Aniedobe M, et al. Fluconazole resistant opportunistic oro-pharyngeal Candida and non-Candida yeast-like isolates from HIV infected patients attending ARV clinics in Lagos, Nigeria. Afr Health Sci. 2008 Sep;8(3):142-8.

15. White TC, Hollemann S, Dy F, Mirels LF, Stevens DA. Resistance mechanisms in clinical isolates of Candida albicans. Antimicrob Agents Chemother. 2002 Jun;46(6):1704-13.
16. Chapman SW, Sullivan DC, Cleary JD. In search of the holy grail of antifungal therapy. Trans Am Clin Climatol Assoc. 2008;119:197-215.

17. Lewis RE, Kepser ME, Pfaller MA. Update on clinical antifungal susceptibility testing for Candida species. Pharmacotherapy. 1998 May-Jun;18(3):509-15.

18. Espinel-lgroff A. Clinical utility of in vitro antifungal susceptibility testing. Rev Esp Quimioter. 2000 Jun;13(2):161-6.

19. Samanarayake YH, Samanarayake LP. Candida krusei: biology, epidemiology, pathogenicity of Candida krusei and clinical manifestations of emerging pathogen. J Med Microbiol. 1994 Nov;41(5):295-310.

20. Back-Brito GN, Mota AJ, Vasconcellos TC, Querido SMR, Jorge AOC. Frequency of Candida spp. in the oral cavity of Brazilian HIV-positive patients and correlation with CD4 cell counts and viral load. Mycopathologia 2009 Feb;167(2):81-7.

21. Clinical and Laboratory Standards Institute. Reference method for broth dilution antifungal susceptibility testing of yeast: approved standart. $2^{\text {nd }}$ edition. Pennsylvania: NCCLS; 2002. $51 \mathrm{p}$.

22. Lyon JP, Moreira LM, Cardoso MAG, Saade J, Resende MA. Antifungal suscepitibility profile of Candida spp. oral isolates obtained from denture wearers. Braz J Microbiol. 2008 Dec;39(4):668-72.

23. Castro TL, Coutinho HDM, Gedeon CC, Santos JM, Santana WJ, Souza LBS. Mecanismos de resistência de Candida sp. a antifúngicos. Infarma. 2006;18(9/10):30-5.

24. Sutton PA, Fothergill AM, Rinaldi MG. Clinically significant fungi. $1^{\text {st }}$ ed. Baltimore: William \& Wilkins; 1998. 471 p.

25. Rautemaa R, Richardson M, Pfaller MA, Perheentupa J, Saxén H. Activity of amphotericin B, anidulafungin, caspofungin, micafungin, posaconazole, and voriconazole against Candida albicans with decreased susceptibility to fluconazole from APECED patients on long-term azole treatment of chronic mucocutaneous candidiasis. Diagn Microbiol Infect Dis. 2008;62(2):182-5.

26. Batista JM, Birman EG, Cury AE. Suscetibilidade a antifúngicos de cepas de Candida albicans isoladas de pacientes com estomatite protética. Rev Odontol Univ São Paulo. 1999;13(4):1-12.

27. Alves SH, Da Mata DA, Azevedo AC, Loreto ES, Boff E, Santurio JM, et al. In vitro activities of new and conventional antimycotics against fluconazole-susceptible and non-susceptible Brazilian Candida ssp. isolates. Mycoses. 2006;49(3):220-5.

28. Miotto NML, Yurgel LS, Cherubini K. Abordagem terapêutica da candidíase bucal. Sci Med. 2004;14(4):364-70.

29. Hamza OJ, Matee MI, Moshi MJ, Simon EN, Mugusi F, Mikx FH et al. Species distribuition and in vitro antifungal susceptibility of oral yeast isolates from Tanzanian HIV- infected patients with primary and recurrent oropharyngeal candidiasis. BMC Microbiol. 2008;8(135):1-9. 